\section{Perceived Community Support Questionnaire: evidence of factorial validity and internal consistency for the Brazilian context}

\author{
Perceived Community Support Questionnaire: \\ evidências de validade fatorial e consistência \\ interna no contexto brasileiro
}

Perceived Community Support Questionnaire: evidencia de la validez factorial y consistencia interna para el contexto brasileño

\begin{abstract}
This work sought to adapt the Perceived Community Support Questionnaire (PCSQ) to the Brazilian context, gathering evidence of its factorial structure and internal consistency. Two studies were performed. The first comprised 119 individuals aged between 21 and 85 years $(M=41.59, S D=15.33)$ with incomplete elementary education (52.1\%). An exploratory factor analysis was conducted and indicated a three-factor structure, explaining $42.3 \%$ of the total variance. The second study comprised 203 participants aged between 19 and 84 years $(M=42.99, S D=12.70)$ with higher education $(17.2 \%)$. The three-factor structure was corroborated by a confirmatory factor analysis $(C F I=0.944$, $T L I=0.931$, RMSEA = 0.088, 90\%CI: 0.072; 0.103), and Cronbach's alpha was adequate. Questionnaire dimensions were named Community Integration, Community Participation, and Community Organizations. Despite the issues involving inverted items, the instrument gathered evidence of factorial validity and internal consistency, showing applicability to further studies.
\end{abstract}

Social Support; Community Integration; Validation Study
Adolfo Pizzinato

Damião Soares de Almeida-Segundo 1

Katia Bones Rocha 2

doi: 10.1590/0102-311X00016120

\author{
Correspondence \\ D. S. Almeida-Segundo \\ Universidade Federal do Rio Grande do Sul. \\ Rua Ramiro Barcelos 2002, Porto Alegre, RS 90035-003, Brasil. \\ damiao_soares@hotmail.com \\ 1 Universidade Federal do Rio Grande do Sul, Porto Alegre, \\ Brasil. \\ 2 Pontifícia Universidade Católica do Rio Grande do Sul, Porto \\ Alegre, Brasil.
}


Social support is a multidimensional variable related to the material or affective resources deriving from an individual social networks 1 and thus associated with individual, community, and social aspects 2,3. Availability of and satisfaction with social support networks impact individuals' selfcare behaviors and health outcomes 4,5. That is, perceived support promotes well-being for evoking feelings of affection and esteem. Although associated with positive mental health and psychosocial adequacy outcomes, the community facet of this perceived support is poorly explored 1,6,7.

Alongside family, work, and school/university, the community is an important socialization space 8 and the material space of social interactions. It is a unique environment where values and norms are shared and experienced and social networks are created, providing resources and stimulating skills development ${ }^{6}$. Community can be defined as a group of individuals, often (but not exclusively) circumscribed to a territory, who frequently interact with each other and develop a social identity and a sense of belonging ${ }^{1}$. According to Farnsworth et al. ${ }^{9}$, in their studies on communities of practice, community may consist of a group of people who work together to acquire and share knowledge for mutual benefits, whether in short- or long-term, and geographical affiliations.

Individuals perceive and internalize social norms, besides regulating expectations regarding social demands, by community interactions 10. An important socialization process occurs through intergenerational coexistence, whereby younger and older adults help supervising and guiding adolescents and children. Adolescents' community participation positively impacts different indicators of psychosocial adjustment, such as self-esteem and well-being ${ }^{6}$. Adolescents with greater community involvement show higher levels of global and social self-esteem and life satisfaction, as well as less loneliness and school violence than those with less community involvement 11.

Some studies showed community support to influence the recovery of individuals with acute health conditions and improve the quality of life of those with chronic conditions 12,13,14,15,16,17. Even when controlled for the effects of sociodemographic factors 18, poor community integration significantly affected the development of depressive disorders among older adults 19 . Low community integration and involvement lead to social isolation. Likewise, when individuals perceive little community support, they may feel lonely and single-handed for adverse situations where they need help and resources. These feelings affect their health, especially within groups that require greater social support, such as older adults and people with chronic diseases 19 . Several studies gathered evidence on the negative health outcomes resulting from social isolation 15,17,20.

The community dimension of social support is particularly relevant in the Latin American context, where cultures are more collectivist than European or North American countries. In Brazil, social assistance as a public policy is guided by the principle of strengthening family and community relations to establish social support networks, thus mobilizing resources and skills to deal with problems 21. Community support is yet more important within contexts of rampant fear of crime and violence, such as Brazil 22, that affects mental health and significantly impacts well-being and quality of life at individual, family, community, and institutional level 15,17,23,24.

Considering the importance of the community construct and aiming to measure this facet of perceived social support, Gracia \& Herrero 6 developed the Perceived Community Support Questionnaire (PCSQ). PCSQ was originally called the Community Social Support Questionnaire 1, which consisted of twenty-five items distributed into four dimensions, each referring to a subscale that could be separately analyzed. The first two assessed the perceived community social support according to informal (e.g., cultural, sports groups) and formal systems (e.g., hospital, public services), where the first was addressed in eleven items and the second in five, and the other subscales measured community integration (four items) and community participation (five items). However, new studies proposed structural changes to the original version due to low internal consistency in the first two scales.

PCSQ current version consists of 14 items divided into three subscales addressing three dimensions of community support: Community Integration (CI), Community Participation (CP), and Community Organizations (CO) 6,7. CI is a four-item scale that assess the sense of belonging and identification with a community or neighborhood. CP is a five-item scale measuring the degree to which respondents are involved in social activities within the community. CO is a five-item scale assessing support provided by voluntary groups and organizations (clubs or recreational and sports services) and political and civic associations (citizens' associations and non-government organizations - NGOs). 
Integration refers to social relationships that shape an individual's sense of identity and belonging to a community. By building social relationships, individuals may access resources and develop multicontextual skills, besides establishing new social relationships 1,25. Feeling that you belong to a larger collective is an important component of the ability to face social challenges and pressures. The second dimension, community participation, refers to a person's degree of engagement in social life and relevant issues. Finally, access to community organizations refers to how individuals perceive social support provided by organizations and groups within their community. Thus, the model enables us to analyze both community role as a source of support and individuals involvement in actions that foster community development 7 .

Social support is a key aspect of health promotion and human development that favors school, family, personal, and social adaptation. Yet, community support is a poorly explored facet of this construct. Some instruments have been developed to measure overall social support 26 or that provided by relatives and friends 27 , but validated instruments to measure perceived community support still lack in the national literature. This study sought to adapt PCSQ ${ }^{6}$ to the Brazilian population and analyze its psychometric properties. Confirmatory factorial analysis (CFA) was used to test the scale factorial structure, and reliability measures were computed.

\section{Method}

\section{Participants and procedure}

The CFA comprised a convenience sample of 322 individuals, mostly female (57.7\%), aged between 19 and 85 years $(M=42.47 ; \mathrm{SD}=13.71)$, with incomplete elementary education (32.6\%), and living in the countryside (65.5\%). Data was collected from September/2017 to December/2019 in Rio Grande do Sul State, Brazil, using a self-administered questionnaire answered by participants under the research team supervision. Once informed of the research objectives and ethical guidelines, those over 18 years of age provided written consent to participate in the study. Our research team included graduated and $\mathrm{PhD}$ or master's students in Psychology. For data collection, our team members approached patients at several Social Assistance Reference Centers (CRAS - Centro de Referência em Assistência Social) in the capital city, metropolitan region, and countryside. After participants were informed their answers would be treated anonymously and confidentially and signed an informed consent form, the questionnaire was administered in remote places within common public areas and took on average 10-15 minutes to be completed. The research project was approved by the Human Research Ethics Committee (CAAE 12842113.5.0000.5336) and the study was conducted according to the recommendations of Resolution n. 466/2012 (Brazilian National Health Council).

\section{Materials}

Participants provided demographic data (e.g., age, gender) and completed the PCSQ ${ }^{6}$. The questionnaire was translated and adapted to Brazilian Portuguese according to the stages recommended by Borsa et al. 28: (1) instrument translation to the new language; (2) synthesis of translated versions; (3) expert evaluation; (4) evaluation by the target audience; (5) reverse translation (back-translation); and (6) pilot study. Upon authorization from the authors of the original scale, six Portuguese speakers native from Spain independently performed the Spanish-Portuguese translation, later analyzed and synthesized by two judges. Then, two psychological evaluation specialists evaluated the translated items and selected those they considered best to match the original meaning. To test the instrument, six CRAS' users were requested to evaluate items understanding and suggest modifications. Two native Brazilians fluent in Spanish performed the back-translation, which was compared with the translation and indicated no need for alterations. The authors compared the versions, making minor adjustments, and proceeded with a pilot study with a group of university students. In all stages, content validity was evaluated according to the consensus among evaluators or experts.

The PCSQ is a 14-item scale that evaluates the perceived community support according to three domains (subscales): CI, comprising four items, such as "I identify myself with my community/neigh- 
borhood (free English translation; "Me identifico com minha comunidade/bairro"); CP, with five items, such as "I participate in social activities promoted by my neighborhood or community" (free English translation; "Participo de atividades sociais do meu bairro ou comunidade"); and CO, with five items, such as "If needed, I could find people who helped me solve my problems" (free English translation; "Poderia encontrar pessoas que me ajudaram a resolver meus problemas"). The first domain, CI, assesses individual's integration with their neighborhood or local community. CP refers to individual's participation in their neighborhood or local community. And $\mathrm{CO}$ refers to the perceived support provided by non-formal associations, such as group of residents and NGOs. Participants indicated their degree of agreement with each statement using a 5 -point Likert scale, where $1=$ strongly disagree and $5=$ strongly agree. Regarding Community Organizations, items were answered according to the following instructions: Now, considering social services, educational projects, rehabilitation centers for chemical dependents, mental health center, etc. - organizations and services provided by the community to its members. Read each statement below carefully and respond based on your own experience. Indicating a number from 1 to 5 , mark to what degree you agree or disagree with each idea (free English translation).

\section{Data analysis}

CFA was conducted on JASP version 0.14 using the diagonal weighted least squares (DWLS) estimator. DWLS is a robust weighted least squares (RWLS) estimator designed to accommodate ordinal and nonnormal observed variables, where data contains a polychoric correlation matrix 29 . DWLS is especially recommended for medium sample sizes $(250<\mathrm{N}<1000)$, and for five or more categories with nonnormal item distributions 29,30,31,32,33 - the exact sample characteristics of this study.

Root mean square error of approximation (RMSEA), Tucker-Lewis index (TLI), comparative fit index (CFI), and chi-square/degrees of freedom $\left(\chi^{2} / \mathrm{df}\right)$ ratio were the fit indices evaluated. Cut-off values of RMSEA $<0.08$ and TLI/CFI $>0.90$ indicated an acceptable fit 34 while cut-off values of RMSEA $<0.06$ and TLI/CFI $>0.95$ indicated good model fit ${ }^{35} \cdot \chi^{2} / \mathrm{df}$ ratio less than 2 were considered acceptable 36 . Factor loadings above 0.40 were considered adequate for factor retention 37 .

To verify the factorial structure of the instrument in the Brazilian context, three models were tested: (1) a unifactorial model; (2) a three-factor model with a second-order factor; and (3) a three first-order factors model. According to Herrero \& Gracia 7, all models tested are considered possible factorial structures. The authors justify testing the second-order factor model based only on (a) the theoretical proposition that PCSQ's 14 items indicate a single latent variable - community support; and (b) covariations among the first-order factors (the magnitude of this association is not informed). Additional evidence was produced by the Schmid-Leiman transformation to verify the presence of empirical support for this model 38. The Schmid-Leiman transformation is an analytical approach to evaluate the degree to which each indicator represents the general factor by postulating a general factor (presumed to underlie all community support items) and estimates items loadings on this hierarchical factor and specific components. Finally, Cronbach's alpha $(\alpha)$ and McDonald's omega $(\omega)$ were calculated to verify the model internal consistency.

\section{Results}

\section{Transcultural adaptation}

Once the two psychological evaluation experts selected the translated items that best corresponded to the meaning conveyed by the original items, the six CRAS' users (participants of the test stage) suggested no modifications and unanimously indicated that the scale was clear regarding instructions, format, and scoring method. Then, the adapted version maintained the 14 items contained in the original instrument. 


\section{Confirmatory factorial analyses (CFA)}

Table 1 shows the fit indices of the models. Besides the three models evaluated, we included two additional models: (4) an adjusted second-order model and (5) an adjusted three first-order factors model. The adjustment consisted in removing items with factor loadings lower than 0.4037 . As including a second-order factor in the model resulted in no changes for the fit indices, Table 1 contains only the values of models 1, 2, and 4; models 3 and 5 (with first-order factors) presented the same fit indices of the corresponding hierarchical models, 2 and 4 . The unidimensional model showed a very poor fit, with lower values than the respective cut-off points, and all other models presented good fit indices.

Models 2 and 4, as well as models 3 and 5, present the same fit indices, sandardized factor loading (SFL), and standard error (SE). Thus, Table 2 shows the factor loadings of the one-dimensional model (1), the second-order model (2), and the second-order adjusted model (4). Models 3 and 5 SFL and ST values are the same as those of their hierarchical correspondents. Table 2 also presents loading in second-order factor (LSF) and SE of the first-order factor.

The first factor, named CI, comprises items 1, 2, and 4 - all with factor loadings higher than 0.40; item 3, "Very few people in my community know who I am" (free English translation; "Muito poucas pessoas da minha comunidade sabem quem eu sou"), was excluded in adjusted models for presenting factor loading below 0.40. CP comprised items 5 to 9 . However, for presenting a value below 0.40 , item 9, "I don't participate in social and recreational activities promoted by my community" (free English translation; "Não participo das atividades sociorecreativas da minha comunidade"), was excluded in adjusted models. CO comprised items 10 to 14, all with factor loadings above 0.40 .

\section{PCSQ higher-order factor structure}

Next, we tested the viability of a higher-order PCSQ dimension: that PCSQ factors represent more differentiated components of the broader community support dimension. Given that Herrero \& Gracia 7 defend the hierarchical factorial structure (a single higher-order PCSQ factor, three lowerorder PCSQ factors), we assessed the appropriateness of hierarchical structure based on adjusted models evidence (4 and 5). Initially, the magnitude of factors correlations in the first-order model (4) was analyzed. Model 4 showed a small or modest coefficient of polychoric correction among factors CI and CO ( $\rho=0.49 ; \mathrm{p}<0.05)$; CI and CP $(\rho=0.45 ; \mathrm{p}<0.05)$, and CP and CO $(\rho=0.26 ; \mathrm{p}<0.05)$. Then, we evaluated the magnitude of factor loadings of PCSQ factors and individual PCSQ items in model 5 and found moderate to strong loadings on the higher-order PCSQ factor in CI (0.92), CP (0.50), and CO (0.53).

We then conducted a Schmid-Leiman transformation to obtain the respective loadings between PCSQ items and the higher-order PCSQ factor, and residualized loadings between PCSQ items and the three first-order PCSQ factors. As shown in Table 3, PCSQ-12 items 1, 2, and 3 (from CI factor) show a salient loading in the higher-order factor, but not within the specific domain. As for items

\section{Table 1}

Fit indices of the Perceived Community Support Questionnaire (PCSQ) factorial structure models (N = 322).

\begin{tabular}{|c|c|c|c|c|c|c|c|c|}
\hline Model & Description & $\chi^{2 / d f}$ & $\chi^{2}$ & df & p-value & CFI & TLI & RMSEA $(90 \% \mathrm{Cl})$ \\
\hline 1 & Unidimensional & 4.87 & 375.34 & 77 & 0.001 & 0.78 & 0.74 & $0.11(0.10 ; 0.12)$ \\
\hline 2 & Second-order & 1.28 & 95.02 & 74 & 0.050 & 0.98 & 0.98 & $0.03(0.03 ; 0.05)$ \\
\hline 4 & Adjusted second-order * & 1.40 & 71.72 & 51 & 0.030 & 0.98 & 0.98 & $0.04(0.01 ; 0.05)$ \\
\hline
\end{tabular}

90\% Cl: 90\% confidence interval; CFI: comparative fit index; df: degree freedom; RMSEA: root mean square error of approximation; TLI: Tucker-Lewis index.

Note: the fit indices of models 3 and 5 (with only first-order factors) presented the same values of the corresponding hierarchical models, 2 and 4.

* Items 3 and 9 of this model were excluded for presenting a factor loading below 0.40 . 
Table 2

Models standardized factor loading, standard error, and first-order factor loading in second-order factor $(\mathrm{N}=322)$.

\begin{tabular}{|c|c|c|c|c|c|c|c|c|c|c|c|c|c|c|}
\hline \multirow[t]{3}{*}{ Items } & \multirow{2}{*}{\multicolumn{2}{|c|}{$\begin{array}{l}\text { Model } 1 \\
\text { CS }\end{array}$}} & \multicolumn{6}{|c|}{ Model 2} & \multicolumn{6}{|c|}{ Model 4} \\
\hline & & & \multicolumn{2}{|c|}{$\mathrm{Cl}$} & \multicolumn{2}{|c|}{ CP } & \multicolumn{2}{|c|}{ CO } & \multicolumn{2}{|c|}{$\mathrm{Cl}$} & \multicolumn{2}{|c|}{ CP } & \multicolumn{2}{|c|}{ CO } \\
\hline & SFL & SE & SFL & SE & SFL & SE & SFL & SE & SFL & SE & SFL & SE & SFL & SE \\
\hline 1 & 0.49 & 0.76 & 0.68 & 0.54 & & & & & 0.68 & 0.53 & & & & \\
\hline 2 & 0.55 & 0.70 & 0.72 & 0.48 & & & & & 0.71 & 0.49 & & & & \\
\hline 3 & -0.08 & 0.99 & -0.08 & 0.99 & & & & & - & - & & & & \\
\hline 4 & 0.42 & 0.82 & 0.55 & 0.70 & & & & & 0.56 & 0.69 & & & & \\
\hline 5 & 0.42 & 0.82 & & & 0.70 & 0.51 & & & & & 0.70 & 0.51 & & \\
\hline 6 & 0.48 & 0.77 & & & 0.78 & 0.39 & & & & & 0.78 & 0.39 & & \\
\hline 7 & 0.48 & 0.77 & & & 0.64 & 0.59 & & & & & 0.64 & 0.59 & & \\
\hline 8 & 0.36 & 0.87 & & & 0.52 & 0.73 & & & & & 0.51 & 0.73 & & \\
\hline 9 & 0.05 & 1.00 & & & 0.11 & 0.99 & & & & & - & - & & \\
\hline 10 & 0.58 & 0.67 & & & & & 0.66 & 0.56 & & & & & 0.66 & 0.56 \\
\hline 11 & 0.52 & 0.73 & & & & & 0.61 & 0.63 & & & & & 0.61 & 0.62 \\
\hline 12 & 0.62 & 0.62 & & & & & 0.76 & 0.41 & & & & & 0.76 & 0.42 \\
\hline 13 & 0.63 & 0.60 & & & & & 0.82 & 0.32 & & & & & 0.82 & 0.32 \\
\hline \multirow[t]{3}{*}{14} & 0.48 & 0.77 & & & & & 0.59 & 0.65 & & & & & 0.59 & 0.65 \\
\hline & & & LSF & SE & LSF & SE & LSF & SE & LSF & SE & LSF & SE & LSF & SE \\
\hline & & & 0.93 & 0.14 & 0.49 & 0.76 & 0.53 & 0.72 & 0.92 & 0.16 & 0.50 & 0.75 & 0.53 & 0.72 \\
\hline
\end{tabular}

Cl: Community Integration; CO: Community Organizations; CP: Community Participation; CS: Community Support; LSF: loading in second-order factor; SE: standard error; SFL: standardized factor loading.

Note: bold entries represent factor loadings above 0.40 of each item on its corresponding factor. Standardized factor loading and standard error for Models 3 and 5 are the same as their corresponding hierarchical models, 2 and 4.

from other domains, items 4, 5, 6, 7, 8, 9, and 12 presented factor loadings below 0.40 in the higherorder factor, and items 10 and 11 had a salient loading in the upper order factor. All CP and CO items saturated within their specific domains.

The relative amount of independent variance attributable to first and second-order factors can be estimated by squaring indicators transformed loadings on the first and second-order factors. For example, $39 \%$ of item 1 variance is explained by the second-order factor (Community Support), and $7 \%$ by the first-order factor (CI). Thus, $5-9 \%$ of items 1, 2, and 3 variance is explained by the specific domain, whereas this value was 20-48\% for all other items. Conversely, 27-39\% of items 1, 2, and 3 variance is explained by the hierarchical factor, while items 6, 7, 9, and 12 varied between $7-10 \%$, and items 4, 5, 8, 10, and 11 from $12-19 \%$.

\section{PCSQ-12 factorial structure and internal consistency}

Given that the fit indices supported the three-factor model, that factor loadings indicated the exclusion of items 3 and 9 from PCSQ-14, and that the additional evidence did not corroborate the secondorder factorial structure, we considered model 5 as the most adequate. Figure 1 shows an adjusted model with three first-order factors of PCSQ-12.

Internal consistency was $\omega=0.74$ and $\alpha=0.77$ for the PCSQ-12; $\omega=0.70$ and $\alpha=0.68$ for CI; $\omega=0.68$ and $\alpha=0.62$ for CP; and $\omega=0.82$ and $\alpha=0.81$ for CO. 
Table 3

Higher-order factor loadings and residualized primary loadings for the 12-Items Perceived Community Support Questionnaire (PCSQ-12; N = 322).

\begin{tabular}{|c|c|c|c|c|c|}
\hline \multirow[t]{2}{*}{ PCSQ-14 (free English translation) } & \multirow[t]{2}{*}{ PCSQ-12 (Portuguese) } & \multirow{2}{*}{$\begin{array}{l}\text { Higher-order } \\
\text { factor loading } \\
\text { General factor }\end{array}$} & \multicolumn{3}{|c|}{ Residualized primary loading } \\
\hline & & & $\mathrm{Cl}$ & CP & CO \\
\hline $\begin{array}{l}\text { 1. I identify myself with my community/ } \\
\text { neighborhood. }\end{array}$ & $\begin{array}{l}\text { 1. Me identifico com a minha comunidadel } \\
\text { bairro. }\end{array}$ & 0.63 & 0.27 & & \\
\hline $\begin{array}{l}\text { 2. My opinions are well received in my } \\
\text { neighborhood or community. }\end{array}$ & $\begin{array}{l}\text { 2. Minhas opiniões são bem recebidas no meu } \\
\text { bairro ou na minha comunidade. }\end{array}$ & 0.65 & 0.28 & & \\
\hline $\begin{array}{l}\text { 4. I feel as if the neighborhood was } \\
\text { something of mine. }\end{array}$ & 3. Sinto o bairro como algo meu. & 0.52 & 0.22 & & \\
\hline $\begin{array}{l}\text { 5. I collaborate in organizations and } \\
\text { associations from my community. }\end{array}$ & $\begin{array}{l}\text { 4. Colaboro nas organizações e associações de } \\
\text { minha comunidade. }\end{array}$ & 0.35 & & 0.61 & \\
\hline $\begin{array}{l}\text { 6. I participate in social activities of } \\
\text { promoted by my neighborhood or } \\
\text { community. }\end{array}$ & $\begin{array}{l}\text { 5. Participo de atividades sociais do meu bairro } \\
\text { ou comunidade. }\end{array}$ & 0.39 & & 0.68 & \\
\hline $\begin{array}{l}\text { 7. I participate in some social or civic } \\
\text { associations. }\end{array}$ & 6. Participo de algum grupo social ou cívico. & 0.32 & & 0.55 & \\
\hline $\begin{array}{l}\text { 8. I attend the support calls that occur } \\
\text { within my community. }\end{array}$ & $\begin{array}{l}\text { 7. Acudo as chamadas de apoio que acontecem } \\
\text { dentro da minha comunidade. }\end{array}$ & 0.26 & & 0.44 & \\
\hline $\begin{array}{l}\text { 10. If needed, I could find people who } \\
\text { helped me solve my problems. }\end{array}$ & $\begin{array}{l}\text { 8. Poderia encontrar pessoas que me ajudaram } \\
\text { a resolver meus problemas. }\end{array}$ & 0.35 & & & 0.56 \\
\hline $\begin{array}{l}\text { 11. If needed, I would find someone to } \\
\text { listen to me when I am down. }\end{array}$ & $\begin{array}{l}\text { 9. Encontraria alguém que me escute quando } \\
\text { estou para baixo. }\end{array}$ & 0.32 & & & 0.52 \\
\hline $\begin{array}{l}\text { 12. If needed, I would find myself a source } \\
\text { of enjoyment. }\end{array}$ & $\begin{array}{l}\text { 10. Encontraria uma fonte de satisfação para } \\
\qquad \mathrm{mim} .\end{array}$ & 0.40 & & & 0.64 \\
\hline $\begin{array}{l}\text { 13. I would be able to cheer myself up to } \\
\text { improve my mood. }\end{array}$ & $\begin{array}{l}\text { 11. Conseguiria animar-me a melhorar meu } \\
\text { estado de ânimo. }\end{array}$ & 0.43 & & & 0.70 \\
\hline $\begin{array}{l}\text { 14. I would relax and easily forget my daily } \\
\text { problems. }\end{array}$ & $\begin{array}{l}\text { 12. Relaxaria e esqueceria com facilidade meus } \\
\text { problemas cotidianos. }\end{array}$ & 0.31 & & & 0.50 \\
\hline
\end{tabular}

Cl: Community Integration; CP: Community Participation; CO: Community Organizations; LSF: loading in second-order factor; SE: standard error; SFL: standardized factor loading.

Note: loadings were transformed using the Schmid-Leiman transformation. PCSQ-14 items 3 and 9 were excluded from the PCSQ-12 Portuguese version and the scale was renumbered.

\section{Discussion}

This study sought to adapt the PCSQ to the Brazilian population and analyze its psychometric properties. By gathering evidence of the instrument validity and reliability, we found good fit indices, but in a different configuration than the original 6,7. After a series of changes based on results of the CFA and a Schmid-Leiman transformation, the data was best fit by an adjusted model with three firstorder factors $\left(\chi^{2} / \mathrm{df}=1.40, \mathrm{CFI}=0.98, \mathrm{TLI}=0.98\right.$, RMSEA $=0.04,90 \% \mathrm{CI}$ : $\left.0.01 ; 0.05\right)$.

Although the $\chi^{2} / \mathrm{df}$ ratio of 14 -item models was slightly better due to a decrease in the 12 -item version degrees of freedom, model 5 (with 12 items) was considered the best choice. For presenting factor loadings below 0.40, items 3 (free English translation: "Very few people in my community know who I am") and 9 (free English translation: "I don't participate in social and recreational activities promoted by my community") were excluded. This may be justified by an inversion in the items content, which lead to problems in response, achieving quite large standard error $(\mathrm{SE}=0.99)$.

These low values of factor loadings may have two possible explanations: acquiescence bias and the sample low educational level. In this case, acquiescence bias refers to the tendency of negative items to cluster in a factor or present low factor loadings when assembling a factor with positive items 
Figure 1

Perceived Community Support Questionnaire (PCSQ-12) factor structure.

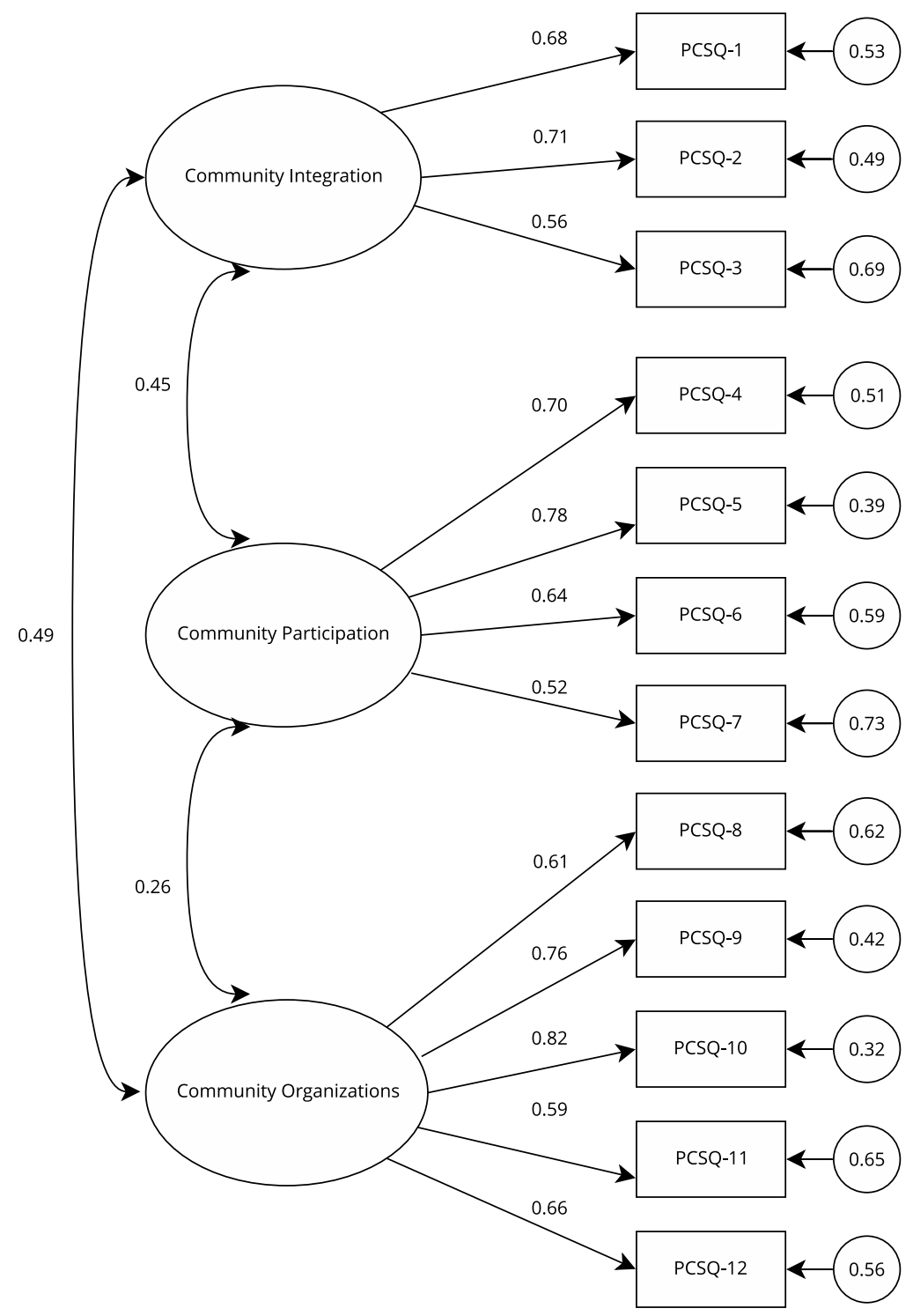

(e.g., 39,40). Inverted items often address issues such as the tendency to group themselves in a separate factor, even when no theoretical basis justifies that factor formation or when they present the lowest factor loadings within the theoretical factor 41,42. Another possible explanation is participants' low education level. Whereas over one third of the study sample of Herrera \& Gracia 7 presented tertiary education, our study sample was mainly composed of people with incomplete primary education (32.6\%). Samples with lower education tend to poorly understand negative items, thus compromising the quality of the items 41 .

Inverted items can also pose a problem for samples with high educational level. Considering that, counterbalancing the items of an instrument (with assertiveness in a direct and inverted sense) is an important method to control acquiescence bias, but requires great precautions 42 , such as balancing 
the amount of direct and inverted items related to each factor of a psychometric instrument. Instruments with few inverted and several direct assertive items, for example, may affect response. In these cases, inverted items usually present the lowest factor loadings, as occurred for PCSQ-14 inverted items (3 and 9) in the CFA performed by Herrera \& Gracia 7.

Once inverse assertions were excluded from the model, the 12 remaining items with salient factorial loadings were organized into three dimensions, as originally proposed 6,7: CI, an individual identification level with the community or neighborhood and the feeling of belonging to that place; $\mathrm{CP}$, the degree of involvement with activities promoted by the community or neighborhood; and $\mathrm{CO}$, the extent to which one can rely on the support of groups or institutions from the community or neighborhood.

We found small to modest correlations between the three factors, which would not justify the inclusion of a second-order factor in the model 38 . However, considering that the original authors of the scale defend a factorial structure 6,7, we gathered additional evidence regarding this model. Our results indicate that the hierarchical model did not fit the data well, because scores variability in $\mathrm{CP}$ and $\mathrm{CO}$ are largely explained by their respective content domains rather than by a common factor to all PCSQ items.

The first three items of the scale presented a high variance explained by the hierarchical factor and a low variance explained by the specific factor, indicating that the general factor computed measured more community integration than community support. After conducting a Schmid-Leiman transformation, we found approximately one third (27-39\%) of CI items variance to be explained by a broader trait reflecting a general factor, whereas less than $10 \%(5-9 \%)$ is explained by the influence of a specific factor. Such general factor seems to be related to individuals identification and reception in the neighborhood or community rather than to community support, given that items 2 (free English translation: "My opinions are well received in my neighborhood or community") and 1 (free English translation: "I identify myself with my community/neighborhood") present the greater levels of higher-order factor loading. Moreover, CI presented the largest first-order factor loading in secondorder factor in the hierarchical model (0.92).

In the Brazilian context, a PCSQ general factor may assume a different configuration associated with the perceived integration and the sense of belonging to a community. Perceived integration was not a common factor between CI, CP, and CO; it explained only most variance in CI items and some variance in the other items. Therefore, although PSCQ-12 measures three distinct indicators of community social support, it does not seem to represent a general construct of community support. Further studies must be conducted to test the instrument factorial structure with other samples.

Regarding internal consistency, we chose to report Cronbach's $\alpha$ values for being widely used among researchers. However, McDonald's $\omega$ is a more appropriate measurement of reliability. Omega values ranged between 0.68 and 0.82 , indicating an adequate consistency, especially in a sample with low educational level. Previous studies also reported values close to $0.7043,44$. Studies conducted with participants whose education level was lower than that of the general population reported lower levels of internal consistency for CP (0.77) and CI (0.74) 43,44,45,46. Surveys conducted with Latin American immigrants in Spain (also with lower education than the general population) found a $0.71 \alpha$ value for the general factor Perceived Community Support 45 and 0.74 for the CI domain 46 .

Finally, our results indicate that the PCSQ version translated and validated to Brazilian populations assesses three distinct aspects associated with community support: CI, CP, and CO; however, it did not support a general and multidimensional configuration of measuring Community Support. Schmid-Leiman transformation revealed that the common or second-order factor explained a small parcel of CP and CO variance. Thus, although we gathered empirical evidence to compute PCSQ-12 three dimensions, it is not enough to calculate an overall score for the instrument.

Despite the contributions, this study has some limitations. First, although our sample may be closer to Brazilian reality in terms of education (given that most psychometry studies were conducted with university students), we worked with a convenience sample, so that further studies must comprise more representative samples of the Brazilian population. We also did not employ other scales to verify the convergent and divergent validity of constructs related to perceived community support. The lack of gold standard instruments in Brazil to measure convergent validity, especially with this type of population (lower education and countryside residents), makes it difficult to analyze this con- 
struct. The literature evinces the association between and predictive power of perceived community support and psychosocial 1,6,8,11 and mental health outcomes 7,12,18,43,44 which can also be tested in a national context. Studies aiming to contribute to investigations on the instrument validity may employ Brazilian-adapted measures, such as the Rosenberg self-esteem scale 47 and the Depression Anxiety and Stress Scale (DASS-21 48). The Brazilian version of the PCSQ can be used by studies seeking to evaluate community aspects of social support related to belonging (CI), reception (CP), and support groups $(\mathrm{CO})$ in a community or neighborhood. Considering its length (12 items) and nature, PCSQ has potential applicability in both health care and social assistance sector. Moreover, in view of the growing interest in psychosocial determinants of health, employing this instrument in studies on this subject may contribute to the field.

\section{Contributors}

A. Pizzinato contributed to the conception and design of the study, data interpretation, article writing, relevant critical review of the intellectual content, final approval of the version to be published and responsible for all aspects of the work in ensuring the integrity and integrity of any part of the work. D. S. Almeida-Segundo contributed to the conception and design of the study, data analysis and interpretation, writing of the article, relevant critical review of the intellectual content and final approval of the version to be published. K. B. Rocha contributed to the conception and design of the study, writing of the article, relevant critical review of the intellectual content and final approval of the published publication.

\section{Additional informations}

ORCID: Adolfo Pizzinato (0000-0002-1777-5860); Damião Soares de Almeida-Segundo (0000-00032407-0583); Katia Bones Rocha (0000-0001-76031709).

\section{Acknowledgments}

To the Brazilian Ministry of Social Development for funding the research through the notice MCTICNPq/MDS-SAGI n. 24/2013. D. S. AlmeidaSegundo receives a doctoral grant from the Brazilina National Research Council (CNPq).

\section{References}

1. Gracia E, Herrero H, Musitu G. Evaluación de recursos y estresores psicosociales en la comunidad. Madrid: Síntesis; 2002.

2. Martí J, Bolíbar M, Lozares C. Network cohesion and social support. Soc Networks 2017; 48:192-201.

3. Uchino BN, Bowen K, Kent R, Mikal J, Fisher EB. Social support and physical health: Models, mechanisms, and opportunities. In: Fisher LE, Cameron A, Christensen U, Ehlert B, Oldenburg F, Snoek A, editors. Principles and concepts of behavioral medicine: a global handbook. New York: Springer; 2018. p. 192-211.

4. Gracia E, Herrero J. Personal and situational determinants of relationship-specific perceptions of social support. Soc Behav Pers 2004; 32:459-76.

5. Canesqui AM, Barsaglini RA. Apoio social e saúde: pontos de vista das ciências sociais e humanas. Ciênc Saúde Colet 2012; 17:1103-14.

6. Gracia E, Herrero J. La comunidad como fuente de apoyo social: evaluación e implicaciones en los ámbitos individual y comunitario. Rev Latinoam Psicol 2006; 38:327-42.

7. Herrero J, Gracia E. Measuring perceived community support: factorial structure, longitudinal invariance, and predictive validity of the PCSQ (Perceived Community Support Questionnaire). J Communit Psychol 2007; 35:197-217. 
8. Estévez JF. La comunidad como contexto educativo. In: Estévez E, Musitu G, editores. Intervención psicoeducativa en el ámbito familiar y social. Madrid: Paraninfo; 2016. p. 199-222.

9. Farnsworth V, Kleanthous I, Wenger-Trayner E. Communities of practice as a social theory of learning: a conversation with Etienne Wenger. British Journal of Educational Studies 2016, 64:139-60.

10. Ballard PJ, Syme SL. Engaging youth in communities: a framework for promoting adolescent and community health. J Epidemiol Community Health 2016; 70:202-6.

11. Crespo-Ramos S, Romero-Abrio A, MartínezFerrer B, Musitu G. Variables psicosociales y violencia escolar en la adolescencia. Psychosocial Intervention 2017; 26:125-30.

12. Gallardo-Peralta LP, Roda AB, Molina-Martinez MA, Moral RS. Family and community support among older Chilean adults: the importance of heterogeneous social support sources for quality of life. J Gerontol Soc Work 2018; 61:584-604.

13. Kashif M, Jones S, Darain H, Iram H, Raqib A, Butt AA. Factors influencing the community integration of patients following traumatic spinal cord injury: a systematic review. J Pak Med Assoc 2019; 69:1337-43.

14. Lee OE, Pantas S, Coyle C. Chorus for community integration and recovery for men with psychiatric disabilities in a supportive housing community. Smith Coll Stud Soc Work 2016; 86:240-57.

15. Pizzinato A, Pagnussat E, Cargnelutti ES, Lobo N, Motta RF. Análise da rede de apoio e do apoio social na percepção de usuários e profissionais da proteção social básica. Estud Psicol (Natal) 2018; 23:145-56.

16. Rocha LF, Oliveira ER, Mota MM. Relação entre apoio social e bem-estar subjetivo em idosos: revisão sistemática. Rev Bras Promoç Saúde 2017; 30:1-13.

17. Uribe MC, Motta RF, Pizzinato A. Red de apoyo social: perspectivas de familias desplazadas en Porto Alegre. Psicol Teor Pesq 2018; 34:e34421.

18. Kim H, Choi YS, Lee JH, Seo AR, Park KS. The association between hopelessness, social support and community integration and depression among elderly living alone. Journal of Agricultural Medicine and Community Health 2016; 41:195-204.

19. Nicholson NR. A review of social isolation: an important but underassessed condition in older adults. J Prim Prev 2012; 33:137-52.

20. Northcott S, Moss B, Harrison K, Hilari K. A systematic review of the impact of stroke on social support and social networks: associated factors and patterns of change. Clin Rehabil 2016; 30:811-31.

21. Secretaria Nacional de Assistência Social, Ministério do Desenvolvimento Social. Concepção de convivência e fortalecimento de vínculos. http://www.mds.gov.br/webarquivos/ publicacao/assistencia_social/Cadernos/con cepcao_fortalecimento_vinculos.pdf (accessed on $23 /$ Oct $/ 2020$ ).
22. Fórum de Segurança Pública. Medo da violência e o apoio ao autoritarismo no Brasil: índice de propensão ao apoio a posições autoritárias. http://www.forumseguranca.org.br/publica coes/medo-da-violencia-e-o-apoio-ao-autori tarismo-no-brasil/ (accessed on 23/Oct/2020).

23. Campo-Arias $\mathrm{OH}$, Herazo E. Prevalencia de síntomas, posibles casos y trastornos mentales en víctimas del conflicto armado interno en situación de desplazamiento en Colombia: una revisión sistemática. Rev Colomb Psiquiatr 2014; 43:177-85.

24. Campos JH, Londoño MC, Correa JC, Tapias NE, Ortega FR, Ballestas LFF. El apoyo social percibido por las víctimas del conflicto armado en Colombia. El Ágora USB 2018; 18:36273.

25. Gracia E, Herrero J. Determinants of social integration in the community: an exploratory analysis of personal, interpersonal and situational variables. J Community Appl Soc Psychol 2004; 14:1-15.

26. Squassoni CE, Matsukura TS. Adaptação transcultural da versão portuguesa do social support appraisals para o Brasil. Psicol Refle Crít 2014; 27:71-80.

27. Baptista MN. Inventário de percepção de suporte familiar - IPSF. São Paulo: Vetor Editora; 2009.

28. Borsa JC, Damásio BF, Bandeira DR. Adaptação e validação de instrumentos psicológicos entre culturas: algumas considerações. Paidéia (Ribeirão Preto) 2012; 22:423-32.

29. DiStefano C, Morgan GB. A comparison of diagonal weighted least squares robust estimation techniques for ordinal data. Struct Equ Modeling 2014, 21:425-38.

30. Beauducel A, Herzberg PY. On the performance of maximum likelihood versus means and variance adjusted weighted least squares estimation in CFA. Struct Equ Modeling 2006; 13:186-203.

31. Rhemtulla M, Brosseau-Liard PÉ, Savalei V. When can categorical variables be treated as continuous? A comparison of robust continuous and categorical SEM estimation methods under suboptimal conditions. Psychol Methods 2012, 17:354-73.

32. Li H. Confirmatory factor analysis with ordinal data: comparing robust maximum likelihood and diagonally weighted least squares. Behav Res Methods 2016; 48:936-49.

33. Zhao Y. The performance of model fit measures by robust weighted least squares estimators in confirmatory factor analysis [Doctoral Dissertation]. State College: Pennsylvania State University; 2015.

34. Hu LT, Bentler PM. Cutoff criteria for fit indexes in covariance structure analysis: Conventional criteria versus new alternatives. Struct Equ Modeling 1999; 6:1-55.

35. Marsh HW, Hau KT, Wen Z. In search of golden rules: Comment on hypothesis-testing approaches to setting cutoff values for fit indexes and dangers in overgeneralizing $\mathrm{Hu}$ and Bentler's (1999) findings. Struct Equ Modeling 2004; 11:320-41. 
36. Bollen KA, Long JS. Testing structural equation models. New York: Sage; 1993.

37. Tabachnick BG, Fidell LS. Using multivariate statistics. $6^{\text {th }}$ Ed. New Jersey: Pearson Education; 2014.

38. Brown TA. Confirmatory factor analysis for applied research. New York: Guildford Press; 2015.

39. Kam CC, Meyer JP. How careless responding and acquiescence response bias can influence construct dimensionality: the case of job satisfaction. Organ Res Methods 2015; 18:512-41.

40. Weydmann G, Hauck Filho N, Bizarro L. Acquiescent responding can distort the factor structure of the BIS/BAS scales. Pers Individ Dif 2020; 152:109563.

41. Damasio BF, Borsa JC. Manual de desenvolvimento de instrumentos psicológicos. São Paulo: Vetor Editora; 2018.

42. Primi R, Hauck-Filho N, Valentini F, Santos D. Classical perspectives of controlling acquiescence with balanced scales. In: Wiberg M, Molenaar D, González J, Bockehnolt U, Kim JS, editors. Quantitative psychology: 84th Annual Meeting of the Psychometric Society. Cham: Springer; 2019. p. 333-45.

43. Herrero J, Fuente A, Gracia E. Covariates of Subjective well-being among Latin American immigrants in Spain: the role of social integration in the community. J Communit Psychol 2011; 39:761-75.
44. Herrero J, Gracia E, Fuente A, Lila M. Desorden social, integración social y bienestar subjetivo en inmigrantes latinoamericanos en España. An Psicol 2012; 28:505-14.

45. Herrero J, Torres A, Fernández-Suárez A, Rodríguez-Díaz, FJ. Generalists versus specialists: Toward a typology of batterers in prison. European Journal of Psychology Applied to Legal Context 2016; 8:19-26.

46. Lila M, Oliver A, Galiana L, Gracia E. Predicting success indicators of an intervention programme for convicted intimate-partner violence offenders: the contexto programme. European Journal of Psychology Applied to Legal Context 2013; 5:73-95.

47. Hutz CS, Zanon C. Revisão da adaptação, validação e normatização da escala de autoestima de Rosenberg. Aval Psicol 2011; 10:41-9.

48. Patias ND, Machado WD, Bandeira DR, Dell'Aglio DD. Depression Anxiety and Stress Scale (DASS-21) - short form: adaptation and validation for Brazilian adolescents. Psico USF 2016; 21:459-69. 


\section{Resumo}

O estudo buscou adaptar o Perceived Community Support Questionnaire (PCSQ) ao contexto brasileiro, coletando evidências sobre a estrutura fatorial e consistência interna. Foram realizados dois estudos. O primeiro estudo incluiu 119 indivíduos entre 21 e 85 anos de idade $(M=41,59 ; D P=15,33)$, a maioria com Ensino Fundamental incompleto $(52,1 \%)$. Foi realizada uma análise fatorial exploratória, que indicou uma estrutura com três fatores que explicava $42,3 \%$ da variância total. O segundo estudo contou com 203 participantes, com idades entre $19 e$ 84 anos $(M=42,99 ; D P=12,70)$ e escolaridade mais alta (17,2\%). A análise fatorial confirmatória corroborou a estrutura com três fatores $(C F I=$ 0,944; $T L I=0,931$; RMSEA = 0,088; IC90\%: 0,072; 0,103), e o coeficiente alfa de Cronbach foi adequado. As dimensões receberam os seguintes nomes: Integração Comunitária, Participação Comunitária e Organizações Comunitárias. Portanto, o instrumento coletou evidências de validade fatorial e de consistência interna, apesar de problemas com itens invertidos, podendo ser utilizado em estudos futuros.

Apoio Social; Integração Comunitária; Estudo de Validação

\section{Resumen}

El objetivo de este estudio fue adaptar el Perceived Community Support Questionnaire (PCSQ) al contexto brasileño, recopilando evidencias de su estructura factorial y consistencia interna. Se realizaron dos estudios. El estudio incluyó a 119 personas con edades comprendidas desde los 21 a los 85 años $(M=41,59$; $S D=15,33)$ y la escuela elemental incompleta $(52,1 \%)$. Se realizó un análisis de factores exploratorio y se señaló una estructura de tres factores, explicando un 42,3\% de la variancia total. El estudio 2 contó con 203 participantes, con edades comprendidas entre los 19 y 84 años $(M=42,99$; $S D=12,70)$ y educación superior $(17,2 \%)$. Un análisis confirmatorio factorial corroboró la estructura de tres factores (CFI = 0,944; $T L I=0,931$; RMSEA = 0,088; IC90\%: 0,072; 0,103) y el alfa de Cronbach fue adecuado. Las dimensiones fueron denominadas: Integración en la Comunidad, Participación Comunitaria y Organizaciones Comunitarias. De este modo, el instrumento recopiló evidencia de la validez factorial y consistencia interna, a pesar de los problemas con los items invertidos, además de poder usarse en futuros estudios.

Apoyo Social; Integración a la Comunidad; Estudio de Validación
Submitted on $29 / \mathrm{Jan} / 2020$

Final version resubmitted on 25/Nov/2020

Approved on 27/Nov/2020 